\title{
HOW DESTRUCTIVE SOCIAL ASPECTS INHIBIT INNOVATION IN THE ORGANISATION
}

\author{
Dariusz Turek*, Agnieszka Wojtczuk-Turek**
}

\begin{abstract}
Background. The innovative behaviours of employees constitute one of the key elements for explaining companies' market competitiveness. Therefore, studying and understanding the mechanisms which trigger individual innovative activity form an important area of analyses owing to which it is possible to design practical recommendations for managerial personnel of organisations.
\end{abstract}

Research aims. Drawing on equity theory, this study describes and explains the relationship between counterproductive work behaviours (CWB), organisational justice and innovative workplace behaviours (IWB). In the proposed model explaining the influence of counterproductive work behaviours on creative activity in the workplace, the organisational justice construct was used - as the mediator of the relationship.

Methodology. The study was conducted anonymously in 2014-2015 on a group of 207 employees studying at post-graduate studies at the Warsaw School of Economics. To assess the direct effects and estimation theoretical model, structural equation modelling was used with AMOS version 23. For the assessment of the indirect effects, the SPSS macro PROCESS was used, which allows for testing mediation effect. Correlation analyses weer also used.

Key findings. The research confirmed a significant statistical relationship between innovative work behaviours and all studied variables: counterproductive work behaviours and organisational justice. On the basis of the analysis using the structural equation model it can be stated that the following factors influence innovative behaviours: counterproductive work behaviours have indirect influence on innovative workplace behaviours via organisational justice. The research shows that both organisational justice and counterproductive work behaviours provide a useful perspective which may facilitate understanding of the factors determining the occurrence of innovative activity in an organisation and may support creative behaviours of HRM and managers.

Keywords: Innovative Workplace Behaviours, Counterproductive Work Behaviours, Organisational Justice, Equity Theory.

\footnotetext{
* Warsaw School of Economics. E-mail: dturek@sgh.waw.pl

*** Warsaw School of Economics. E-mail: awojtc@sgh.waw.pl
} 


\section{INTRODUCTION}

Innovation is considered an important element in building performance and competitive advantage in contemporary organisations operating on the global market (Prahalad \& Krishnan, 2010; Rosenbusch et al., 2011). Thus, innovative work behaviours (IWB) of employees, oriented at creating activities, implementing, and/or effective application of beneficial 'novelties' at any given level of organisation, are considered highly desirable (West \& Farr, 1989; Zhou \& Shalley, 2003; Nisula \& Kianto, 2016). They comprise a variety of forms of activity, e.g. searching for possibilities, creating, testing, implementing, and promoting ideas (Scott \& Bruce, 1994; Kleysen \& Street, 2001; Yuan \& Woodman, 2010; Anderson et al., 2014), which comprise two main stages of innovative work behaviour: behaviours directed at creation (problem recognition and generation of ideas) and implementation (promoting and implementing ideas) (Dorenbosch et al., 2005; Hülsheger et al., 2009; Anderson et al., 2014).

These behaviours are crucial in the context of the companies' development based on implementing innovations, and therefore the management theorists and practitioners are interested in the research of IWB predictors (Wojtczuk-Turek, 2012).

Meta-analyses of IWB predictors, conducted in recent years, indicate the significance for innovative activity of both individual predispositions of employees (abilities, personality, emotions, motivation, attitudes) (da Costa et al., 2015), as well as education level, work characteristics and climate, professional expectations, resources available in the company, relations with leaders, and leadership type (Hülsheger et al., 2009; Hammond et al., 2011). Moreover, as indicated by Harari and the team (Harari et al., 2016), the type of employees' behaviour correlates positively not only with job performance, but also with organisational citizenship behaviour, and negatively with counterproductive work behaviour. These results fit with the dominant interactional perspective of IWB study, basing on the assumption that an employee behaviour is conditioned by both individual and contextual factors (Anderson et al., 2014, p. 1300). The present study also draws on the assumption that innovative activity of employees incorporates both environmental and individual factors. 
Although studies on innovative workplace behaviours at work have been conducted for over 20 years and there is a considerable amount of knowledge in this sphere, there are still questions which have eluded conclusive answers. One of such issues is the "dark side" of innovation predictors and processes (Anderson et al., 2014, p. 1322). Some - relatively few - studies in this area indicated that innovation attempts can be provoked by negative work role evaluations and moods (Binnewies \& Wornlein, 2011; Bledow et al., 2013), or experienced conflict in the organisation (Chen et al., 2005). At the same time, a number of other analyses pointed out that destructive environment and work climate may hinder innovative activity (Hülsheger et al., 2009; Hammond et al., 2011).

Accordingly, it is worthwhile to pursue efforts to explain when and how the harmful factors of work environment may explain innovative behaviours at work.

In this context, an important question arises about the mechanism of such an impact and, at the same time, about the search for factors (mediators) which can strengthen or attenuate the adverse effect of negative organisational behaviours. It seems that the variable which may contribute to understanding the nature of the relationship between destructive organisational factors (negative organisational behaviours) and innovation activities is the construct of organisational justice. According to the equity theory (Adams, 1965), an entity compares (measures) its own work effort (resources, competence, energy, etc.) with the effort of other people holding similar positions, and then refers it to the obtained results. If an entity sees this ratio as equal to the ratios of other people, then they recognise it as a state of justice. However, if these ratios are uneven, a sense of injustice arises, which means that a person believes they receive insufficient or excessive awards for their work. This leads to specific behavioural consequences, which may result in higher or lower efficiency of units, better or worse quality of work, absence or voluntary departure from the workplace (Adams, 1965). Therefore, counterproductive work behaviours of other employees create grounds for unjust assessments, for example, in a situation where an employee observes that another individual, despite a lesser involvement in their work, receives the same or bigger rewards, or if they are favoured despite stealing or performing mobbing actions.

In their studies, Zhang, Lepine, Buckman, and Wei (2014) established that justice explains the relationship between two dimensions 
of job stressors - challenges and hindrances (both challenge and hindrance are constant aspects of taking up innovative activities and, at the same time, they may result from counterproductive behaviours) and dimensions of work performance, such as task performance and creativity (Zhang et al., 2014). It appears, then, that a sense of justice may mitigate the adverse effects of counterproductive behaviours on innovation.

The purpose of the study presented in this article has been to describe and explain the relationship between Counterproductive Work Behaviours of other employees (CWB) and Innovative Workplace Behaviours (IWB) initiated and performed by employees. In the proposed model explaining the influence of CWB on creative activity in the workplace the Organisational Justice (OJ) construct was used as the mediator of the relationship. Our proposed theoretical model, based on Adam's equity theory, is depicted in Figure 1.

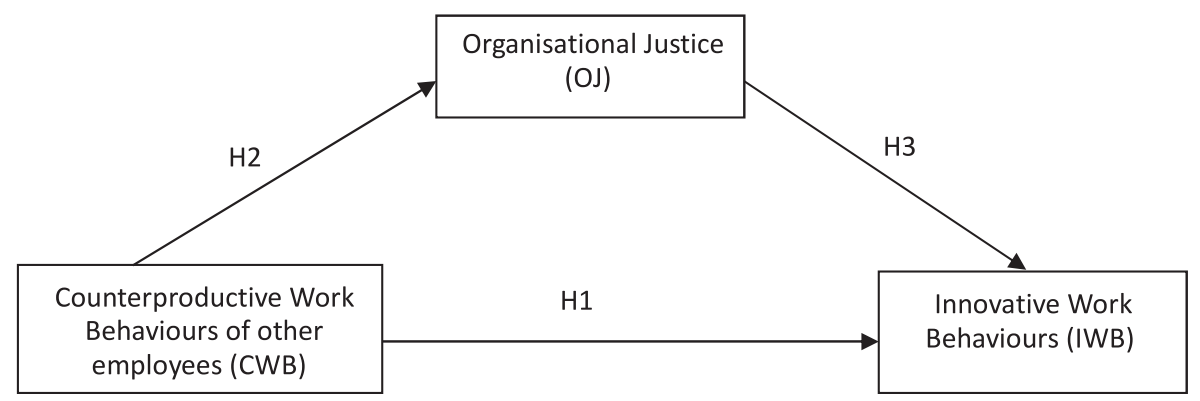

Figure 1. Theoretical model of hypotheses

Source: own study.

At the basic level, we propose that CWBs of other employees are negatively related to organisational innovativeness of individuals. However, those "negative behaviours of employees" do not suffice to inhibit innovative activity of individuals. Therefore, we assume that the character of the interrelations of this variable with innovative behaviours is indirect. In other words, CWB of other employees inhibit innovativeness in the organisation only when the employees feel that in their activities they are not treated fairly by managers. 


\section{THEORETICAL BACKGROUND}

From the perspective of facilitation of innovative behaviours in the workplace, a crucial role is played by positive perception of others and of the overall social climate (Wojtczuk-Turek \& Turek, 2016). The perception of an organisation as supportive versus as hindering towards one's work finds its reflection in the attitudes and behaviours of employees. Should employees - from their own point of view - perceive the customs observed in an organisation as friendly and sense that organisational activities are aimed at maintaining such a situation, they become ready for greater work commitment and for acting towards the organisation's benefit (May et al., 2004). Various studies show that group innovation increases when individuals feel that their ideas and innovative actions are accepted and encouraged, that they are expected to behave in such a manner and that the environment is safe for them to express their own ideas openly and to participate in decision-making (Anderson \& West, 1998; Somech \& Drach-Zahavy, 2013; Montani et al., 2014). It appears that group factors, and not individual or job factors, play a greater role in the phase of implementing suggestions (Axtell et al., 2000).

Counterproductive behaviours are situated on the opposite pole. They are manifested at the interpersonal level in the form of, for instance, favouritism, gossip, slander, verbal abuse, sexual harassment, mobbing, and at the organisational level - as sabotage, corruption, theft, slowing down work, or wasting resources (Robinson \& Bennett, 1995; Spector et al., 2006; Turek, 2012). These behaviours affect not only the perpetrators and their victims, but also the entire organisational environment, influencing task performance of employees, their relationships, and quality of life. Their influence on innovative behaviours in the workplace is therefore obvious.

The social dimension of counterproductive behaviours in relation to creative activities undertaken by employees may manifest itself by way of creating a negative social climate, but also by intentional taking of actions, such as: constraining creative tasks (e.g. through manipulation of information), creating a negative impression and undermining the competence of individuals undertaking a creative initiative, policies impeding the implementation of innovative projects, theft of an idea's authorship, or conflicts (particularly visible 
within teamwork). Considering the creative activities, Janssen (2003) underlines the fact that innovative employees are more susceptible to involvement in interpersonal conflicts with co-workers when facing resistance to an innovative idea. A conflictual situation may be of an interpersonal and/or task-related nature. As regards the impact on innovation, negative behaviours also include 'process conflict' and 'relationship conflict' (Isaken \& Ekvall, 2010). In the case of the first type of conflict, it denotes a discrepancy in the method of task execution, including the choice of methods by the group, whereas relationship conflict means presence of personal and emotional tensions within the team. The latter conflict type leads to lower productivity of the team (Pelled, 1996). While conflict has a negative impact on innovation, a debate facilitates it (through constructive exchange of views) (Isaken \& Ekvall, 2010), and is considered an important dimension of a creative climate (Jensen \& Beckmann, 2009).

The negative impact on innovation of counterproductive behaviours of other employees (regardless of the type) may result from the effects brought by these behaviours, namely: stress, negative mood (anxiety, anger, depression), psychological states (low self-esteem, low self-efficacy at work and low job satisfaction), somatic functioning (health problems), cognitive disorders (difficulties with concentration), and organisational functioning (low productivity and involvement) (Keashly \& Harvey, 1998). These effects may exacerbate overloads arising from the nature of creative tasks: cognitive overload (e.g. significant cognitive effort over a long period of time) and emotional overload (stress resulting from taking risks, overcoming barriers in the implementation of ideas, the need to cope with a situation of failure or lack of support and acceptance of ideas). It is emphasised that in the context of undertaking creative activity, particularly inhibiting influence is exerted by defensive emotions, such as: anxiety, apprehension, fear (Dacey \& Lennon, 1998), i.e. the emotions which are associated with counterproductive behaviours of others. Farr and Ford (1990) point out that stress can cause employees to focus on well-learned and habitual actions at work (such as those involved in routine tasks). Thus, overloads resulting from stress can make it difficult to undertake creative activity.

All the above considerations allow the formulation of Hypothesis 1:

Hypothesis 1: There is a negative relationship between counterproductive behaviour and innovative work behaviours. 
In the context of knowledge of the negative impacts of counterproductive behaviours, a question arises as to whether only the direct experience of counterproductive behaviours can limit innovative behaviours in the workplace. It appears that this is not the case, and the knowledge of the presence of such behaviours or the fact that such behaviours are observed may also reduce motivation for creative activities in the workplace, for instance, because of limited access to the resources which are necessary to perform creative tasks, resulting from counterproductiveness of others. Also, Kanter (1984) identified 'skunk works' activities as tasks, performed by employees during organisational time and with the use of organisational resources, important because they stimulate and encourage innovation.

Apart from the lack of access to resources for individuals undertaking creative activities, another problem is the unjust distribution of the said resources. Thus, the aforementioned organisational justice - defined as employees' perception of what is fair in the professional environment (Colquitt et al., 2005) - might also be important in stimulating innovative behaviours, similarly to its confirmed influence on motivation, productivity, cooperation (Cohen-Charash \& Spector, 2001; Colquitt et al., 2001), knowledge sharing (Park et al., 2009), and creativity (Khazanchi \& Masterson, 2011). The concept of justice is most often recognised in four dimensions: distributive justice (which means perceived fairness within granting of organisational resources, such as salaries, bonuses, promotions); procedural justice (which means perceived fairness regarding the procedures used in the distribution of resources); informational justice (which means perceived fairness regarding the need to obtain information on employees); interactive justice (which means perceived fairness in terms of being treated with dignity, in particular by those who are responsible for the management and supervision of the organisation) (Colquitt et al., 2005, p. 5). In this perspective, justice is not an objective standard or characteristics of functioning of an organisation or processes of managing employees, but only a subjective belief, valuation, or assessment by an individual of the nature of, or of what is happening in, an organisation. In the case of inequities, on the other hand, employees are encouraged to maintain or restore equity. The perceived equity diverts the attention of employees and thus lowers the employees' motivation and innovativeness because these issues are strongly interrelated (Amabile, 1988). 
As emphasised by the authors, depending on its type, justice may determine creativity in various ways because the separate dimensions of justice are mutually independent (Bies, 2005) and they explain creative behaviours in the organisation in different ways (Simmons, 2011).

Janssen (2000) showed that employees behaved more innovatively in response to higher job demand when they perceived that the reward-effort ratio was fair. Moreover, IWB could produce stress when distributive and procedural fairness were low. Procedural fairness could buffer the stress caused by innovative employees in the context of low distributive justice (Janssen, 2004). IWB was positively related to the stress reactions of job-related anxiety and burnout only when the levels of both distributive fairness and procedural fairness were low (Janssen, 2004). Shih and Susanto (2011) claim that innovative employees who perceive distributive fairness may experience happiness because they perceive that the organisation has met the desired outcomes. Such perceptions may also signal to innovative employees that the organisation will grant similar rewards in the future.

While the sense of distributive justice is an important dimension of employees' functioning, studies show that employees care more for fair procedures of distribution than for fair distribution itself (Colquitt et al., 2005). In the context of innovative behaviours Simmons (2011) proves this assumption and indicates a significant positive relationship between procedural justice and creative performance. As the author explains, perception of fair procedures motivates employees to contribute as these procedures show that managers respect and appreciate them and their contribution. At the same time, fair procedures may increase self-esteem, regardless of the obtained results (Simmons, 2011). Increasing creative performance is also observed when organisations are supportive and promote voicing of opinions with regard to policies and procedures (Amabile \& Gryskiewicz, 1988). In addition, studies have proven the existence of a relationship between distributive justice and creativity in situations where openness to experience was a moderator (Simmons, 2011).

However, apart from the direct impact of organisational justice on innovation activity in the workplace, its influence may be seen through other variables - in studies by Young (2012) it was found that organisational justice promotes innovative behaviours through 
a psychological mechanism of perceived organisational support (POS). On the other hand, organisational justice may be placed in the role of a mediator. In their studies, Zhang, Lepine, Buckman and Wei (2014) found that it serves as a mechanism which explains negative relationships between the two dimensions of job stressors (challenges and hindrance) and five dimensions of job performance, including task performance, helping, voice, counterproductive behaviour and creativity. It is statistically significant that justice combines positively with creative behaviour, task performance, helping behaviour, voice behaviour, and negatively with counterproductive behaviour (Zhang, Lepine, Buckman \& Wei, 2014). Therefore, it seems that a sense of justice may mitigate the adverse effects of counterproductive (stress generating) behaviours on innovation. With reference to the above findings, two further hypotheses were formulated:

Hypothesis 2: There is a negative relationship between counterproductive behaviours and organisational justice.

Hypothesis 3: Perceived of organisational justice is positively related to innovative behaviours.

\section{METHOD}

\section{Participants and procedure}

The study was conducted anonymously in 2014-2015 on a group of 220 employees studying at post-graduate studies at the Warsaw School of Economics. For this reason, the group was homogeneous in terms of education (Table 1). The choice of that group does not constitute the method bias since, in general, research on the IWB is conducted in relation to employees with higher education: knowledge workers (de Jong \& den Hartog, 2010), individuals who attended a forum of innovative services (responsible for developing innovative service) (Ko $\& \mathrm{Lu}, 2010)$, employees from knowledge-intensive business service (KIBS) (Tuominen \& Toivonen, 2011; Wojtczuk-Turek, 2016).

The studied population consisted mostly of women (62\%), people aged 26-35 years old (65\%), occupying non managerial positions (62\%), in corporations employing more than 1,000 employees (32\%). The Kruskal-Wallis test of the group variance for aggregated CWB, 
OJ and IWB measures, respectively, revealed no significant difference. For this reason, non-response bias was not established and was thus not a major concern in this study.

Table 1. Description of the sample

\begin{tabular}{|l|l|c|c|}
\hline \multicolumn{2}{|c|}{ Characteristic Number } & $(\mathrm{N}=207)$ & Percentage \\
\hline \multirow{3}{*}{ Gender } & Female & 129 & 62.3 \\
& Male & 78 & 37.7 \\
\hline \multirow{5}{*}{ Age } & Up to 25 & 29 & 14 \\
& $26-35$ & 135 & 65.2 \\
& $36-45$ & 37 & 17.9 \\
& $46-55$ & 6 & 2.9 \\
& Over 55 & 0 & 0 \\
\hline \multirow{3}{*}{ Tducation } & Secondary & 0 & 0 \\
& Academic high school & 207 & 100 \\
\hline \multirow{3}{*}{ Job position } & Up to 1 year & 16 & 7.7 \\
& $1-5$ years & 112 & 38.2 \\
& Over 5 years & 78 & 54.1 \\
\hline \multirow{5}{*}{ Company size } & Managerial & 129 & 37.7 \\
& Non-managerial & 17 & 62.3 \\
\hline & Up to 9 employees & 31 & 8.2 \\
& 10-49 employees & 54 & 15 \\
& 21-250 employees & 39 & 26.1 \\
& Ovi-1,000 employees & 66 & 18.8 \\
& Over 1,000 employees & & 31.9 \\
\hline
\end{tabular}

Source: own study.

According to the procedure, each participant was given an identical set of tests, and presented with the same instruction. The subjects completed the set of tests individually, without direct contact with the investigator. In result, 220 completed questionnaires were returned, and after removing questionnaires containing errors, 207 questionnaires were qualified to analysis.

To test for the proposed hypotheses, were performed using different methods. To assess the direct effects and the estimation theoretical model, structural equation modelling was used with AMOS 23. For the assessment of the indirect effects, the SPSS macro PROCESS was used with recommended 5,000 bootstrap sampling (Hayes, 2013).

\section{Measures}

The conducted survey took into consideration the following set of variables (see Appendix for full details): 
Innovative Work Behaviour (IWB) - was measured with the 14item Innovative Behaviour Questionnaire developed by Kleysen and Street (2001). It is one single measure of innovative behaviour with good construct validity. The data was provided by choosing an answer to every statement from a 6 -point scale, with: 1 - never; 6 - always. In the process of cultural adaptation of the instrument, statistical analyses were performed for the sake of secondary verification of the reliability. The a coefficient of reliability for the whole instrument amounted to 0.92. The Confirmatory Factor Analysis showed good fit between the tool and the data $\mathrm{X}^{2}=47.950, \mathrm{df}=37 ; \mathrm{p}=0.107$; RMSEA $=0.042$; $\mathrm{CFI}=0.993 ; \mathrm{GFI}=0.954 ; \mathrm{NFI}=0.966$; $\mathrm{TLI}=0.987$.

Organisational Justice (OJ) - was measured with the 20-item questionnaire developed by Niehoff and Moorman (1993), whose reliability was estimated to be $=0.94$. In the process of validation of the tool a confirmatory factor analysis was conducted. The analysis indicated good fit $X^{2}=262.502, \mathrm{df}=156, \mathrm{p}=0.046$; RMSA $=0.058$, $\mathrm{CFI}=0.973, \mathrm{GFI}=0.951, \mathrm{NFI}=0.937, \mathrm{TLI}=0.953$. A participant of the questionnaire responded to the statements contained in this research tool by using a 5-point Likert scale, where 1 - completely untrue, and 5 - absolutely true.

Counterproductive Work Behaviour (CWB) - was measured with the authors' own 21-statement questionnaire based on Kaptein (2010) and Bennett and Robinson (2000) and Vardi and Weitz (2004) questionnaires. In the process of tool validation, an explanatory and confirmatory factor analysis was conducted $X^{2}=221.144$, df $=172$; $\mathrm{p}=0.007 ; \mathrm{RMSEA}=0.038 ; \mathrm{CFI}=0.972 ; \mathrm{GFI}=0.945 ; \mathrm{NFI}=0.958, \mathrm{TLI}$ $=0.965$ and reliability was estimated, which amounted to $\alpha=0.91$. The study participants filled out the questionnaire using a 5-point Likert scale, where 1 - never, and 5 - always.

The covariates were controlled: gender ( $1=$ female; $2=$ male), age ( $1=$ below $25 ; 2=26-35 ; 3=36-45 ; 4=46-55 ; 5=$ over 55$)$, education ( $1=$ higher; $2=$ other $)$, job position $(1=$ managerial; $2=$ non-managerial), work experience ( $1=$ below 1 year; $2=1-5 ; 3=$ over 5 years), and company size ( $1=$ up to 9 employees; $2=10-49$ employees; $3=51-250$ employees; $4=251-1,000$ employees; $5=$ over 1,000 employees). A control of these covariates is recommended in the reference literature (Agrawal, 2014).

All the questionnaires, apart from the questionnaire for the measurement of CWB, were used in the self-report form. In the tool for 
CWB measurement, the respondents appraised the behaviours of a colleague with whom they have been cooperating for at least a year and who reports to the same superior. In the case of the remaining variables, although there is a risk of common method bias (Podsakoff et al., 2003), the use of research tools in the self-report form is factually justified. For example, as suggested by Agrawal (2014, p. 55), employees are best suited to self-report work behaviours because they are the ones who are aware of the subtle things they do that enable them to perform better. Self-reported measures of innovative work behaviours are not uncommon in the management literature $(\mathrm{Ng} \&$ Feldman, 2012) and have been found to converge with supervisory ratings and objective workplace behaviour measures. In examining the psychological and attitudinal measures in previous studies in the industrial/organisational literature, Spector (2006) found negligible effects of self-reported questionnaires on the common method bias.

Due to the fact that research contained the same source of data (for the two variables) - there appears a risk of systematic response bias that could either inflate or deflate responses (Podsakoff et al., 2003). To avoid this bias two methods were used: Harman's single factor test and common latent factor (CLF). Harman's single factor test showed that the single factor of each variable explains less than the suggested threshold of $50 \%$ of variance. Analyses of CLF showed

that regression weights for models with and without common latent factors revealed deltas much less than .20, which is a commonly used threshold. No tests revealed any common method bias.

\section{RESULTS OF THE ANALYSIS}

The first step of the analyses was to evaluate the research model. For this purpose the method of structural equation modelling (SEM) was used, included in the AMOS 23 version package. In the procedure of models estimation the maximum likelihood method was applied, and the following indexes were used as fit criteria: RMSEA, CFI, GFI, NFI, and TLI. Chi-square test $\left(\mathrm{X}^{2}\right)$ was also used.

It is assumed that for $\chi^{2}$ the smaller the value of the scale and the significance, the closer the model is to being a perfect fit. In the case of RMSEA it is indicated that values less than 0.05 generally indicate a good fit, while values between 0.05 and 0.08 suggest an 
acceptable fit (Bagozzi \& Yi, 2012), whereas for the indexes CFI, GFI, NFI and TLI, commonly accepted are the values 0.95 and above $(\mathrm{Hu}$ \& Bentler, 1999).

During the estimation it was demonstrated that the requested experimental model is well adapted to the data $\left(\mathrm{X}^{2}=2.126, \mathrm{df}=1\right.$, $\mathrm{p}=0.145 ; \mathrm{RMSEA}=0.074, \mathrm{CFI}=0.982, \mathrm{GFI}=0.977, \mathrm{NFI}=0.968$, TLI $=0.947$ ) and explains $21 \%$ of the variance of the results.

In the second step, in order to verify the hypotheses, the analysis of the correlations for individual variables was conducted. The results of inter-correlation, together with the descriptive statistics (mean and standard deviations) are presented in the Table 2.

Table 2. Descriptive statistics and intercorrelations

\begin{tabular}{|c|c|c|c|c|c|c|c|c|c|c|}
\hline & $M$ & $S D$ & 1 & 2 & 3 & 5 & 6 & 7 & 8 & 9 \\
\hline 1. IWB & 3.77 & .884 & $(.92)$ & & & & & & & \\
\hline 2. CWB & 2.11 & .554 & $-.273^{* *}$ & (.91) & & & & & & \\
\hline 3. OJ & 3.34 & .795 & $.387^{* *}$ & $-.432^{* * *}$ & $(.94)$ & & & & & \\
\hline 5. Sex & 1.38 & .497 & .107 & .024 & .084 & - & & & & \\
\hline 6. Age & 2.10 & .654 & $.184^{*}$ & -.088 & .088 & .96 & - & & & \\
\hline $\begin{array}{l}\text { 7. Work } \\
\text { experience }\end{array}$ & 2.46 & .637 & $.234^{*}$ & -.085 & .060 & $.160^{*}$ & $.447^{* *}$ & - & & \\
\hline $\begin{array}{l}\text { 8. Job } \\
\text { position }\end{array}$ & 1.63 & .494 & $-.317^{* *}$ & .079 & $-.189^{*}$ & $-.245^{* * *}$ & $-.278^{* * *}$ & $-.439 * *$ & - & \\
\hline 9. Education & 1.02 & .138 & -.105 & -.041 & -.028 & -.037 & $-.190^{* * *}$ & -.127 & .036 & - \\
\hline $\begin{array}{l}\text { 10. Compa- } \\
\text { ny size }\end{array}$ & 3.51 & 1.299 & .047 & -.039 & .105 & .094 & .075 & $.152^{*}$ & -.028 & -.092 \\
\hline
\end{tabular}

Notes: IWB - Innovative Work Behaviour; CWB - Counterproductive Work Behaviour; OJ - Organisational Justice. In brackets Cronbah's a reliability.

$\mathrm{N}=207 ; * p<0.05: * * p<0.01$

Source: own study.

As indicated in Table 2, negative correlations were observed between innovative behaviours and CWB $(r=-0.273, \mathrm{p}<0.01)$, OJ and CWB $(\mathrm{r}=-0.432, \mathrm{p}<0.01)$ as well positive between IWB and OJ $(\mathrm{r}=0.387$, $\mathrm{p}<0.01)$. Consequently, the obtained results reflect the inter-correlations regarding the determinants of innovative behaviours in the workplace theoretically postulated in hypotheses 1,2 and 3. 
Among the control variables, positive correlations were obtained between innovative behaviours and age $(r=0.184, \mathrm{p}<0.05)$, and job experience $(r=0.234, p<0.05)$, while negative correlations were obtained between IWB and job position $(r=-0.317, p<0.01)$. Additional variables, as shown in the model 1 in Table 3 explains in total 10\% of the variance of the results for the IWB (Table 3). These results are congruent with the results obtained by other authors, who point out that subsidiary variables are significantly related to creative behaviours and should be controlled under research procedures in the studies of such types of activity (Young, 2012).

Table 3. Effect on Innovative Work Behaviour

\begin{tabular}{|l|c|c|c|}
\hline & Model 1 & Model 2 & Model 3 \\
\hline Independent variable & & $-.212^{* * *}$ & -.098 \\
\hline CWB & & & $.297^{* * *}$ \\
\hline OJ & & & \\
\hline Contrating variable & & & .034 \\
Sex & .046 & .066 & .070 \\
Age & .090 & .073 & -.064 \\
Education & -.061 & -.073 & $-.185^{* *}$ \\
Job position & $-.248^{* * *}$ & $-.236^{* * *}$ & .094 \\
Work experience & .070 & .064 & -.036 \\
Company size & .001 & .004 & .24 \\
\hline $\mathrm{R}^{2}$ & .12 & .17 & .21 \\
\hline$\Delta \mathrm{R}^{2}$ & .10 & .14 & $7.724^{* * *}$ \\
\hline $\mathrm{F}$ & $4.685^{* * *}$ & $5.711^{* * *}$ & 207 \\
\hline $\mathrm{N}$ & 207 & 207 & \\
\hline
\end{tabular}

Notes: CWB - Counterproductive Work Behaviour; OJ - Organisational Justice.

$* p<0.05 ; * * p<0.01 ; * * * \mathrm{p}<0.001$

Source: own study.

The verification of the hypotheses was conducted with the use of inference based on regression equations and the SEM method. In the case of hypothesis 1 indicating a direct negative dependencies of CWB with IWB - as shown in the model 2 in Table 3 - high results were not achieved $(B=-0.212, \mathrm{p}<0.01)$. This indicates that the "destructive" activities of other employees are not an intense and direct motive for limiting creativity of other employees and their willingness to implement new ideas or products. For this variable explains only $5 \%$ of the variance of the results. 
In the case of hypotheses 2 and 3, it was assumed that the mediator of the relationship between the CWB and the IWB is a sense of organisational justice. According to the procedure suggested by Baron and Kenny (1986, p. 1177), the first assessed elements were the relationships between $\mathrm{CWB}$ and $\mathrm{OJ}(B=-0.382, \mathrm{p}<0.01)$, then the relationships between the CWB and the IWB, which also proved to be significant at $\mathrm{p}<0.01$, and, finally, the mediator relationship with the dependent variable $(B=-0.379, \mathrm{p}<0.01)$. After entering all the variables in the regression model (model 3 in Table 3 ), a decrease of the predictor's value (CWB) and an increase in the mediator's value were obtained (OJ). This is consistent with the guidelines of the quoted authors and also is a confirmation that organisational justice is a full mediator between the CWB and the IWB. The $\Delta R^{2}$ variance expressed in model 3 increased by $7 \%$, which confirms the correctness of inference.

Bootstrapping was used to quantify the effect of mediation, with 5,000 bootstrap sampling (Hayes, 2013). The indirect effect of CWB on IWB through organisational justice is significant, as indicated by a bootstrapping confidence interval that does not comprise zero $(B=0.3$, LLCI $=0.398$, ULCI $=0.159)$. Thus, the CWB indirectly $(B=-0.298$, $p<0.01$ ) explains $9 \%$ of the variance IWB, and therefore it is more than in the direct explanation. Therefore, considering the above, there are grounds for confirmation of hypothesis 2 and hypothesis 3 , and the rejection of hypothesis 1 . Thus, destructive climate in the organisation indirectly affects the innovative behaviour of the employees and is a barrier for them only if they perceive that they are not treated fairly in terms of distribution of the resources, procedures, transmitted information, or the interaction with superiors.

\section{DISCUSSION}

While the reference literature on predictors of innovation presents a number of studies proving a positive impact of certain negative phenomena in an organisation on creativity, such as rule-breaking, violation of standard operating procedures or risk-taking (Baucus et al., 2008), these are counterproductive behaviours and they definitely constitute its inhibitors. They do not only undermine basic human values, such as the right to dignity, respect, equality, safety, and security (perhaps 
for these reasons they are identified and/or included in the category of unethical behaviours) but also, in terms of an organisation, they lead to a decrease in work effectiveness and negatively affect the economic value of companies. In the social aspect, they cause a lowered sense of identification with the team and reduce integration, create conflicts and a negative atmosphere of cooperation. They are responsible for low coherence of the group and low quality of interpersonal relationships, as well as for a reduction in the occurrence of altruistic behaviours. Studies clearly show that innovation in the workplace is encouraged by behaviours from the opposite pole: availability of support (Amabile, 2004; Janssen, 2005), atmosphere of trust (Ruppel \& Harrington, 2000), individual perception of ethical leadership and group ethical leadership (Yidong \& Xinxin, 2013), perceived climate (Wang \& Rode, 2010), and perceived safety (Anderson \& West, 1998).

At the same time, a direct negative relationship between counterproductive behaviours and innovation in the workplace, postulated in this research model, has not been empirically confirmed, which may be found surprising. On the other hand, in this case, the study of counterproductiveness was based on the use of the tool in which a participant presents only an opinion regarding the occurrence of destructive behaviours in a company, rather than referring them to themselves (i.e. having to answer the question whether the participant herself/himself was a victim of counterproductiveness). Therefore, it is possible that negative behaviours of other employees may not constitute an inhibitor of creative activities in a situation when such behaviours do not directly attack the 'innovator'. Of course this does not mean that even if the 'innovator' is not a victim of counterproductiveness, he or she does not bear the costs of its occurrence in the organisation. These behaviours may, in fact, impede access to organisational resources, important from the perspective of creative tasks (which may be limited, for example, because of theft occurring in the company) or cause obstacles in the implementation of innovative projects, etc.

Additionally, the conducted research indicates, in fact, a negative impact of counterproductive behaviours on innovation of employees. However, this impact is not direct, but occurs through a mediator, i.e. organisational justice. The obtained research results allow to accept the hypothesis of a negative relationship of counterproductiveness with organisational justice and, at the same time, its positive relationship 
with innovative behaviours. It can, therefore, be concluded that a destructive climate in an organisation, being the result of counterproductive behaviours of other employees, is an inhibitor of innovation in a situation where employees undertaking IWB perceive that they are not treated fairly in terms of distribution of resources, procedures, transmitted information, or interaction with their supervisor. This result is consistent with the results of the already quoted analyses, in which justice motivates individuals to creative performance (innovation contribution) (Simmons, 2011), eliminates stress reactions of job-related anxiety and burnout (Janssen, 2004), explains the negative relationship between occupational stressors (challenges and hindrance) and counterproductive behaviour and their positive relations with creativity (Zhang et al., 2014), and even may be able to buffer the negative influence of IWB on conflict with co-workers (Shih \& Susanto, 2011).

It seems that the role of organisational justice is crucial in explaining the initiative to undertake creative activity. As Simmons (2011) emphasises, when employees notice inequity they become motivated to maintain or restore equity. Moreover, inequity works against employees' motivation to perform creative activities because they concentrate on the perceived inequities instead. As a result, creativity may become inhibited because it strongly relies on the internal motivation of employees. Furthermore, it appears that in the process of triggering innovation in entities, apart from intrinsic motivation, emphasised by researchers (Amabile, 2004), an important role is also played by external motivation, while creativity is stimulated by a reward adequate to the creative effort (Eisenberger \& Cameron, 1996), also including financial rewards (Ramamoorthy et al., 2005). Thus, in the light of research related to innovation (Simmons, 2011), an important mechanism which shapes innovative commitment, according to the equity theory (Adams, 1965), is perception by an employee of the degree of fulfilment of their expectations by the employer in terms of 'rewards' for their effort, which creates the feeling of procedural justice. In contrast, the key mechanism showing how the sense of justice may weaken the negative impact of counterproductive behaviours on innovation in the workplace requires further in-depth analyses. 


\section{CONCLUSIONS AND LIMITATIONS}

The analyses discussed in this paper suggest that counterproductive behaviour of other employees is not directly related to innovative behaviours. At the same time, the study has shown that influence of counterproductive behaviour on employee's innovativeness occurs through a mediator, i.e. organisational justice.

While the findings presented in this study broaden the to-date perspective on the research of innovativeness, the study is still not free from certain shortcomings.

Firstly, the study had a cross-sectional and historical character, which directly precludes observations as to the causality in the interrelations between the analysed variables, and in the discussion of the results. A conclusive verification of the relationships assumed in the research model might only be conducted via experimental and/or longitudinal studies.

Secondly, using a questionnaire designed for innovative behaviours research might cause common method biases (Podsakoff et al., 2003), although several statistical diagnostics (e.g. confirmatory factor analysis, Harman's single factor test, and common latent factor) showed that a common method bias was not a serious concern in the presented study. Furthermore, all of the study's variables were measured with established scales, which can mitigate measurement error, thereby decreasing the common method bias (Spector, 2006).

Thirdly, since the participants were sampled from different organisations, it was necessary to control the variables of "support for creativity", "creative climate", or "organisational culture".

Moreover, the study did not control whether the participants were affected by counterproductive behaviours or were just observing their occurrence in their organisation. This aspect should be considered and included in future studies.

In future studies it might be worthwhile to undertake an attempt to replicate the conducted analyses in order to better comprehend the mechanism of CWB and OJ influence over IWB, while simultaneously extending the range of the examined mediators and including the individual and contextual moderators in the research model. 


\section{REFERENCES}

Adams, J.S. (1965). Inequity in social exchange. In: L. Berkowitz (ed.), Advances in Experimental Social Psychology. New York: Academic Press, 267-299.

Agrawal, U.A. (2014). Linking justice, trust and innovative work behaviour to work Engagement. Personnel Review, 43(1), 41-73.

Amabile, T.M. \& Gryskiewicz, S.S. (1988). Creative human resource in the R\&D laboratory: How environment and personality affect innovation. In: R.L. Kuhn (ed.), Handbook of creative and innovative managers. New York: McGraw Hill, 501-524.

Amabile, T.M. (1988). A model of creativity and innovation in organizations. In: B.M. Shaw \& L.L. Cummings (eds.), Research in organisational behaviour. Greenwich, CT: JAI Press, 123-167.

Amabile, T.M. (2004). Stimulate creativity by fueling passion. In: E.A. Locke (ed.), The Blackwell handbook of principles of organisational behaviour. Oxford, UK: Blackwell Publishing, 331-341.

Anderson, N. \& West, M.A. (1998). Measuring climate for work group innovation: Development and validation of the team climate inventory. Journal of Organisational Behaviour, 19, 235-258.

Anderson, N., Potočnik, K. \& Zhou, J. (2014). Innovation and creativity in organizations: A State-of-the-science review, prospective commentary, and guiding framework. Journal of Management, 40(5), 1297-1333

Axtell, CM., Holman, D.J., Unsworth, K.L., Wall, T.D., Waterson, P.E. \& Harrington, E. (2000). Shop floor innovation: Facilitating the suggestion and implementation of ideas. Journal of Occupational and Organisational Psychology, 73, 265-285.

Bagozzi, R. \& Yi, Y. (2012). Specification, evaluation, and interpretation of structural equation models. Journal of the Academy of Marketing Science, 40(1), 8-34.

Baron, R.M. \& Kenny, D.A. (1986). The moderator-mediator variable distinction in social psychological research: Conceptual, strategic, and statistical considerations. Journal of Personality and Social Psychology, 51, 1173-1182.

Baucus M.S., Norton, W.I., Baucus, D.A. \& Human, A.E. (2008). Fostering creativity and innovation without encouraging unethical behaviour. Journal of Business Ethics, 81, 97-115.

Bennett, R.J. \& Robinson, S.L. (2000). Development of a measure of workplace deviance. Journal of Applied Psychology, 85, 349-360. 
Bies, R.J. (2005). Are procedural justice and interactional justice conceptually distinct? In: J. Greenberg \& J.A. Colquitt, Handbook of organisational justice. New Jersey: Lawrence Erlbaum, 85-112.

Binnewies, C. \& Wornlein, S.C. (2011). What makes a creative day? A diary study on the interplay between affect, job stressors, and job control. Journal of Organisational Behaviour, 32, 589-607.

Bledow, R., Rosing, K. \& Frese, M. (2013). A dynamic perspective on affect and creativity. Academy of Management Journal, 56, 432-450.

Chen, G., Liu, C. \& Tjosvold, D. (2005). Conflict management for effective top management teams and innovation in China. Journal of Management Studies, 42, 277-300.

Cohen-Charash, Y. \& Spector, P.E. (2001). The role of justice in organizations: A meta-analysis. Organisational Behaviour and Human Decision Processes, $86,278-321$.

Colquitt, J.A., Conlon, D.E., Wesson, M.J., Porter, C.O.L.H. \& Ng, K.Y. (2001). Justice at the millennium: A Meta-analytic review of 25 years of organisational justice research. Journal of Applied Psychology, 86, 425-445.

Colquitt, J.A., Greenberg, J. \& Zapata-Phelan, C.P. (2005). What is organisational justice? A historical overview. In: J. Greenberg \& J.A. Colquitt (eds.), Handbook of organisational justice. New Jersey: Lawrence Erlbaum, 3-56.

Da Costa, S., Paez, D., Sanchez, F., Garaigordobil, M. \& Gondim, S. (2015). Personal factors of creativity: A second order meta-analysis. Journal of Work and Organisational Psychology, 31, 165-173.

Dacey, J.S. \& Lennon, K.H. (1998). Understanding Creativity. The Interplay of Biological, Psychological, and Social Factors. San Francisco: Jossey-Bass.

De Jong, J. \& Den Hartog, D. (2010). Measuring innovative work behaviour. Creativity and Innovation Management, 19(1), 23-36.

Dorenbosch, L., van Engen, M.L. \& Verhagen M. (2005). On-the-job innovation: The impact of job design and human resource management through production ownership. Creativity and Innovation Management, 14(2), 129-141.

Eisenberger, R. \& Cameron, J. (1996). Detrimental effects of reward: Reality or myth? American Psychologist, 51, 1153-1166.

Farr, J.L. \& Ford, C.M. (1990). Individual innovation. In: M.A. West \& J.L. Farr (eds.), Innovation and creativity at work. Chichester, UK: Wiley, 63-80.

Hammond, M.M., Neff, N.L., Farr, J.L., Schwall, A.R. \& Zhao, X. (2011). Predictors of individual-level innovation at work: A meta-analysis. Psychology of Aesthetics, Creativity, and the Arts, 5(1), 90-105.

Harari, M.B., Reaves, A.C. \& Viswesvaran, Ch. (2016). Creative and innovative performance: A meta-analysis of relationships with task, citizenship, and 
counterproductive job performance dimensions. European Journal of Work and Organisational Psychology, 25(4), 495-511.

Hayes, A.F. (2013), An Introduction to Mediation, Moderation, and Conditional Process Analysis: A Regression-Based Approach. New York: The Guilford Press.

Hu, L.T. \& Bentler, P.M. (1999). Cut off criteria for fit indices in covariance structure analyses: conventional criteria versus new alternatives. Structural Equation Modelling, 6(1), 1-55.

Hülsheger, U.R., Anderson, N. \& Salgado, J.F. (2009). Team-level predictors of innovation at work: A comprehensive meta-analysis spanning three decades of research. Journal of Applied Psychology, 94, 1128-1145.

Isaken, S.G. \& Ekvall, G. (2010). Managing for innovation: the two faces of tension in creative climates. Creativity and Innovation Management, 19(2), 73-88.

Janssen, O. (2000). Job demands, perceptions of effort-reward fairness, and innovative work behaviour. Journal of Occupational and Organisational Psychology, 73(3), 287-302.

Janssen, O. (2003). Innovative behaviour and job involvement at the price of conflict and less satisfactory relations with co-workers. Journal of Occupational and Organisational Psychology, 76, 347-364.

Janssen, O. (2004). How fairness perceptions make innovative behaviour more or less stressful. Journal of Organisational Behaviour, 25, 201-215.

Janssen, O. (2005). The joint impact of perceived influence and supervisor supportiveness on employee innovative behaviour. Journal of Occupational and Organisational Psychology, 78(4), 573-579.

Jensen, M.B. \& Beckmann, S. (2009). Determinants of innovation and creativity in corporate branding: findings from Denmark. Journal of Brand Management, 16(7), 468-479.

Kanter, R.M. (1984). The Change Masters. New York: Simon \& Schuster.

Kaptein, M. (2010). The ethics of organizations: A longitudinal study of the U.S. working population. Journal of Business Ethics, 92, 601-618.

Keashly, L. \& Harvey, S. (1998). Emotional abuse in the workplace. Journal of Emotional Abuse, 1, 85-117.

Khazanchi, S. \& Masterson, S.S. (2011). Who and what is fair matters: A multi-foci social exchange model of creativity. Journal of Organisational Behaviour, $32,86-106$.

Kleysen, R.F. \& Street, Ch.T. (2001). Toward a multi-dimensional measure of individual innovative behaviour. Journal of Intellectual Capital, 2(3), 284-296.

Ko, H-T. \& Lu, H.-P. (2010). Measuring innovation competencies for integrated services in the communications industry. Journal of Service Management, 21(2), 162-190. 
May, D.R., Gilson, R.L. \& Harter, L.M. (2004). The psychological conditions of meaningfulness, safety and availability and the engagement of the human spirit at work. Journal of Occupational and Organisational Psychology, 77(1), 11-37.

Montani, F., Odoardi, C., Battistelli, A. (2014). Individual and contextual determinants of innovative work behaviour: Proactive goal generation matters. Journal of Occupational and Organisational Psychology, 87(4), 645-670.

Ng, T.W. \& Feldman, D.C. (2012). A comparison of self-ratings and non-self-report measures of employee creativity. Human Relations, 65(3), 1021-1047.

Niehoff, B.P. \& Moorman, R.H. (1993). Justice as a mediator of the relationship between methods of mentoring and organisational citizenship behaviour. Academy of Management Journal, 36(3), 527-556.

Nisula A.-M. \& Kianto, A. (2016). The antecedents of individual innovative behaviour in temporary group innovation. Creativity and Innovation Management, 25(4), 431-444.

Park H., Yeon Son S., Lee S. \& Yun S. (2009). Organisational justice and knowledge sharing. International Journal of Business Research, 9(4), 180-184.

Pelled, L.H. (1996). Demographic diversity, conflict, and work group outcomes: An intervening process theory. Organization Science, 7, 615-631.

Podsakoff, P.M., MacKenzie, S.B., Lee, J.-Y. \& Podsakoff, N.P. (2003). Common method biases in behavioural research: A critical review of the literature and recommended remedies. Journal of Applied Psychology, 88(5), 879-903.

Prahalad, C.K. \& Krishnan, M.S. (2010). Nowa era innowacji. Warszawa: Wydawnictwo Naukowe PWN.

Ramamoorthy, N., Flood, P.C., Slattery, T. \& Sardessai, R. (2005). Determinants of innovative work behaviour: Development and test of an integrated model. Creativity and Innovation Management, 14(2), 142-150.

Robinson, S.L. \& Bennett, R.J. (1995) A typology of deviant workplace behaviours: A multidimensional scaling study. Academy of Management Journal, 38(2), $555-572$.

Rosenbusch, N., Brinckmann, J. \& Bausch, A. (2011). Is innovation always beneficial? A meta-analysis of the relationship between innovation and performance in SMEs. Journal of Business Venturing, 26, 441-457.

Ruppel, C.P. \& Harrington, S.J. (2000). The relationship of communication, ethical work climate, and trust to commitment and innovation. Journal of Business Ethics, 25, 313-328.

Scott, S.G. \& Bruce, R.A. (1994). Determinants of innovative behaviour: A path model of individual innovation in the workplace. Academy of Management Journal, 37(3), 580-607. 
Shih, H.-A. \& Susanto, E. (2011). Is innovative behaviour really good for the firm? Innovative work behaviour, conflict with coworkers and turnover intention: moderating roles of perceived distributive fairness. International Journal of Conflict Management, 22(2), 111-130.

Simmons, A. (2011). The influence of openness to experience and organisational justice on creativity. Creativity Research Journal, 23(1), 9-23.

Somech, A. \& Drach-Zahavy, A. (2013). Translating team creativity to innovation implementation: the role of team composition and climate for innovation. Journal of Management, 39(3), 684-708.

Spector, P.E. (2006). Method variance in organisational research: truth or urban legend? Organisational Research Methods, 9(2), 221-232.

Spector, P.E., Fox, S., Penney, L.M., Bruursema, K., Goh, A. \& Kessler, S. (2006). The dimensionality of counterproductivity: Are all counterproductive behaviours created equal? Journal of Vocational Behaviour, 68, 446-460.

Tuominen, T. \& Toivonen, M. (2011). Studding innovation and change activities in KIBS through the lens of innovation behaviour. International Journal of Innovation Management, 15(2), 393-422.

Turek, D. (2012). Kontrproduktywne zachowania pracowników w organizacji. Przejawy, uwarunkowania, ograniczanie. Warszawa: Difin.

Vardi, Y. \& Weitz, E. (2004). Misbehaviour in Organizations. New Jersey: Lawrence Elbaum Associates.

Wang, P. \& Rode, J.C. (2010). Transformational leadership and follower creativity: The moderating effects of identification with leader and organisational climate. Human Relations, 63(8), 1105-1028.

West, M.A. \& Farr, J.L. (1989). Innovation at work: Psychological perspectives. Social Behaviour, 4, 15-30.

Wojtczuk-Turek, A. \& Turek, D. (2016). The significance of perceived social-organization climate for creating employees' innovativeness: The mediating role of person-organization fit. Management Research Review, 39(2), 167-195.

Wojtczuk-Turek, A. (2012). Zachowania innowacyjne w pracy. Warszawa: Difin,.

Wojtczuk-Turek, A. (2016). Wspieranie produktywności pracowników wiedzy. Warszawa: PWN.

Yidong, T. \& Xinxin, L. (2013). How ethical leadership influence employees' innovative work behaviour: A perspective of intrinsic motivation. Journal of Business Ethics, 116, 441-455.

Young, L.D. (2012). How to promote innovative behaviour at work? The role of justice and support within organizations. The Journal of Creative Behaviour, 46(3), 220-243. 
Yuan, F. \& Woodman, R.W. (2010). Innovative behaviour in the workplace: The role of performance and image outcome expectations. Academy of Management Journal, 53(2), 323-342.

Zhang, Y., Lepine, J., Buckman, B.R. \& Wei, F. (2014) It's not fair... or is it? The role of justice and leadership in explaining work stressor-job performance relationship. Academy of Management Journal, 57(3), 675-697.

Zhou, J. \& Shalley, C. (2003). Research on employee creativity: A critical review and directions for future research. In: J.J. Martocchio \& G.R. Ferris (eds.), Research in personnel and human resources management. Oxford, England: Elsevier Science, 165-217. 


\section{APPENDIX}

\begin{tabular}{|c|c|c|}
\hline & $\begin{array}{l}\text { Factor } \\
\text { Loadings } \\
\text { (CFA) }\end{array}$ & $\mathrm{CA}$ \\
\hline Innovative Work Behaviour (adapted form Kleysen \& Street, 2001) & & .92 \\
\hline In your current job, how often do you: & & \\
\hline $\begin{array}{l}\text { Look for opportunities to improve an existing process, technology, product, } \\
\text { service or work relationship? }\end{array}$ & .732 & \\
\hline $\begin{array}{l}\text { Recognize opportunities to make a positive difference in your work, } \\
\text { department, organization, or with customers? }\end{array}$ & .779 & \\
\hline $\begin{array}{l}\text { Pay attention to non-routine issues in your work, department, organiza- } \\
\text { tion or the market place? }\end{array}$ & .799 & \\
\hline Generate ideas or solutions to address problems? & .821 & \\
\hline Define problems more broadly in order to gain greater insight into them? & .744 & \\
\hline Experiment with new ideas and solutions? & .778 & \\
\hline Test-out ideas or solutions to address unmet needs? & .831 & \\
\hline Evaluate the strengths and weaknesses of new ideas? & .776 & \\
\hline Try to persuade others of the importance of a new idea or solution? & .872 & \\
\hline Push ideas forward so that they have a chance to become implemented? & .928 & \\
\hline Take the risk to support new ideas? & .827 & \\
\hline Implement changes that seem to be beneficial? & .873 & \\
\hline $\begin{array}{l}\text { Work the bugs out of new approaches when applying them to an exist- } \\
\text { ing process, technology, product or service? }\end{array}$ & .795 & \\
\hline $\begin{array}{l}\text { Incorporate new ideas for improving an existing process, technology, } \\
\text { product or service into daily routines? }\end{array}$ & .931 & \\
\hline Organisational Justice (adapted form Niehoff \& Moorman, 1993) & & .94 \\
\hline My work schedule is fair. & .531 & \\
\hline I think that my level of pay is fair. & .563 & \\
\hline I consider my work load to be quite fair. & .520 & \\
\hline Overall the rewards I receive are quite fair. & .544 & \\
\hline I feel that my job responsibilities are quite fair. & .527 & \\
\hline Job decisions are made by the manager in a biased manner. & .497 & \\
\hline $\begin{array}{l}\text { My manager makes sure that all employee concerns are heard before } \\
\text { job decisions are made. }\end{array}$ & .649 & \\
\hline $\begin{array}{l}\text { To make job decisions, my manager collects accurate and complete } \\
\text { information. }\end{array}$ & .681 & \\
\hline
\end{tabular}




\begin{tabular}{|c|c|c|}
\hline & $\begin{array}{l}\text { Factor } \\
\text { Loadings } \\
\text { (CFA) }\end{array}$ & $\mathrm{CA}$ \\
\hline $\begin{array}{l}\text { My manager clarifies decisions and provides additional information } \\
\text { when requested by employees. }\end{array}$ & .763 & \\
\hline All job decisions are applied consistently to all affected employees. & .579 & \\
\hline $\begin{array}{l}\text { Employees are allowed to challenge or appeal job decisions made by } \\
\text { their managers. }\end{array}$ & .573 & \\
\hline $\begin{array}{l}\text { When decisions are made about my job, the manager treats me with } \\
\text { kindness and consideration. }\end{array}$ & .741 & \\
\hline $\begin{array}{l}\text { When decisions are made about my job, the manager treats me with } \\
\text { respect and dignity. }\end{array}$ & .760 & \\
\hline $\begin{array}{l}\text { When decisions are made about my job, the manager is sensitive to my } \\
\text { personal needs. }\end{array}$ & .797 & \\
\hline $\begin{array}{l}\text { When decisions are made about my job, the manager deals with me in } \\
\text { a truthful manner. }\end{array}$ & .846 & \\
\hline $\begin{array}{l}\text { When decisions are made about my job, the manager shows concern for } \\
\text { my right as employee. }\end{array}$ & .812 & \\
\hline $\begin{array}{l}\text { Concerning decisions made about my job, the manager discusses with } \\
\text { me the implications of the decisions. }\end{array}$ & .820 & \\
\hline $\begin{array}{l}\text { The manager offers adequate justification for decisions made about my } \\
\text { job. }\end{array}$ & .884 & \\
\hline $\begin{array}{l}\text { When making decisions about my job, the manager offers explanations } \\
\text { that make sense to me. }\end{array}$ & .873 & \\
\hline My manager explains very clearly any decisions made about my job. & .880 & \\
\hline Counterproductive Work Behaviour & & .91 \\
\hline Wasting, mismanaging, or abusing organisational resources. & .593 & \\
\hline Discriminating against employees. & .725 & \\
\hline Violating workplace health and safety rules or principles. & .606 & \\
\hline Violating organisational standards or regulations. & .572 & \\
\hline Being late at work. & .763 & \\
\hline Calling in sick to take a day off. & .787 & \\
\hline Taking extra personal time (lunch hour, breaks, early departure). & .647 & \\
\hline Taking longer than necessary to do a job. & .585 & \\
\hline Pilfering company materials and supplies. & .617 & \\
\hline Falsifying time/quality/quantity reports. & .752 & \\
\hline Being rude towards employees/customers/applicants. & .803 & \\
\hline Refusing to help or cooperate. & .730 & \\
\hline
\end{tabular}




\begin{tabular}{|l|c|c|}
\hline & $\begin{array}{c}\text { Factor } \\
\text { Loadings } \\
\text { (CFA) }\end{array}$ & CA \\
\hline Not providing other employees with necessary information. & .643 & \\
\hline Intentionally disturbing other employees in the performance of their work. & .564 & \\
\hline Raising an expense account. & .648 & \\
\hline Sending aggressive or humiliating emails to an employee. & .586 & \\
\hline Divulging confidential information. & .556 & \\
\hline Passing blame for errors to an innocent co-worker. & .753 & \\
\hline Claiming credit for someone else's work. & .728 & \\
\hline Giving/accepting gifts in exchange for preferential treatment. & .724 & \\
\hline Authorizing a subordinate to violate company rules. & .715 & \\
\hline
\end{tabular}

Notes: standardized regression weights; All factor loadings are significant at $p<0.01$; CFA = Confirmatory Factor Analysis; CA = Cronbach's Alpha. 


\title{
W JAKI SPOSÓB DESTRUKCYJNY KLIMAT SPOKECZNY OGRANICZA ZACHOWANIA INNOWACYJNE W ORGANIZACJI?
}

\begin{abstract}
Abstrakt
Tło badań. Zachowania innowacyjne pracowników stanowią jeden z kluczowych elementów pozwalajaccych wyjaśniać konkurencyjność firm na rynku. W związu z tym badanie i rozumienie mechanizmów wyzwalających aktywność innowacyjna jednostek są ważnym obszarem analizy, dzięki któremu można wypracowywać praktyczne rekomendacje dla osób zarządzających organizacjami.
\end{abstract}

Cel badań. W artykule, na podstawie teorii równości Adamsa, opisano i wyjaśniono relacje pomiędzy kontrproduktywnymi zachowaniami w organizacji, poczuciem sprawiedliwości organizacyjnej i zachowaniami innowacyjnymi. W proponowanym modelu teoretycznym zachowania kontrproduktywne innych pracowników uznane zostały za inhibitor zachowań innowacyjnych. Poczucie sprawiedliwości pełniło rolę mediatora relacji pomiędzy zmiennymi.

Metodologia. Badania zostały przeprowadzone w latach 2014-2015 na grupie 207 uczestników studiów podyplomowych uczestniczących na zajęciach w Szkole Głównej Handlowej w Warszawie. Do analizy danych wykorzystano model korelacyjny, metodykę SEM (Structural Equation Modelling) w programie AMOS wersja 23, a także SPSS macro PROCESS do oceny efektu mediacji.

Kluczowe wnioski. Badania potwierdziły statystyczne zależności pomiędzy zachowaniami innowacyjnymi a pozostałymi analizowanymi zmiennymi: negatywnie z zachowaniami kontrproduktywnymi innych pracowników i pozytywnie z sprawiedliwością organizacyjna. Na podstawie analiz metodą SEM można powiedzieć, że zachowania kontrproduktywne w sposób pośredni, poprzez mediacje sprawiedliwości organizacyjnej, tłumaczą przejawiane przez pracowników zachowania innowacyjne. Ponadto badania pokazuja, że ujmowanie w analizach wskazanych zmiennych może być użyteczne w wyjaśnianiu innowacyjności w miejscu pracy i służyć zarówno działom HR, jak i menedżerom do podnoszenia innowacyjności firm.

Słowa kluczowe: zachowania innowacyjne w pracy, zachowania kontrproduktywne, sprawiedliwość organizacyjna, teoria równości. 